\title{
EFFECT OF SYNBIOTIC ON GROWTH AND ANTIOXIDANT STATUS OF BLOOD IN BROILER CHICKEN
}

\author{
Sanja J. Popović ${ }^{1 *}$, Ljiljana M. Kostadinović ${ }^{1}$, Nikola M. Puvača ${ }^{2}$, Jovanka D. Lević ${ }^{1}$, Olivera M. \\ Đuragić ${ }^{1}$, Bojana M. Kokić ${ }^{1}$, Ivana S. Čabarkapa ${ }^{1}$, Marina V. Vranješ ${ }^{3}$ \\ ${ }^{1}$ University of Novi Sad, Institute of Food Technology, Bulevar cara Lazara 1, 21000 Novi Sad, Serbia \\ ${ }^{2}$ University of Novi Sad, Faculty of Agriculture, Trg Dositeja Obradović 8, 21000 Novi Sad, Serbia and \\ Patent Co, Ćetkovića 1a, 24211 Mišićevo, Serbia \\ ${ }^{3}$ Institute for Application of Science in Agriculture, Bulevar despota Stefana 68b, \\ 11000 Belgrade, Serbia
}

\author{
*Corresponding author: \\ Phone: +381214853775 \\ Fax: $+38121-450-725$ \\ E-mail address: sanja.popovic@fins.uns.ac.rs
}

\begin{abstract}
In the present study, the impact of synbiotic, compared to control treatment (CON), on growth performance and antioxidative status of broilers blood was investigated. The experiment was carried out on a total of 500 one-day-old broiler chickens of both sexes. The broilers were divided into two treatments with five replicates, based on a completely randomized design. The control treatment was fed basal diet, while experimental treatment was supplemented with synbiotic in addition of $1 \mathrm{~g} / \mathrm{kg}$ of feed (SYN) in finisher period that lasted from 15 to 42 days of age. Diet supplementations with synbiotic led to increased body weight of broilers, compared to the control treatment. During the last 28 days, feed conversion ratio was significantly $(\mathrm{P}<0.05)$ improved in the synbiotic treatment $(2.12)$, compared to the control treatment (2.21). The serum glutathione peroxidase, peroxidase, glutathione reductase and catalase activities were significantly higher $(P<0.05)$, except of superoxide dismutase, in the supplemented treatment compared to the control treatment. Furthemore, there were noticed significant decreases $(P<0.05)$ in malondialdehyde and glutathione content in the supplementary treatment. Based on the previously mentioned, it can be concluded that synbiotic can be applied as a growth promoter and as a natural antioxidant feed additive in broilers diet.
\end{abstract}

Key words: Broiler, synbiotic, growth promoter, antioxidant status

\section{INTRODUCTION}

Growth promoters are widely used in a nutritionally balanced diet of broiler chikens affecting the exploitation of maximum genetic potential of the host, in terms of growth as well as improvement in feed conversion efficiency. Beside favorable effects on animal health and growth, the use of antibiotics in animal nutrition can cause a serious risk to animal, but to human health also (Puvača et al., 2013). For this reason, the application of antibiotics as growth promoters (AGP) in the animal feed production has been banned in the European Union since January 2006 (Cas- tanon, 2007). Subsequently, with increasing demands for safe food and heightened consumer concerns over the side effects of conventional antibiotics on poultry, the search for alternative strategies regarding safe food is intensified. As a result, in recent years there are large interests in the use of synbiotics (nutritional supplements combining probiotics and prebiotics in a form of synergism) as livestock feed additives (Marrero et al., 2013). The main activity of synbiotic is to establish and maintain healthy intestinal micro flora. A prebiotic is defined as a 
nondigestible food ingredient that positively affects the host by selectively stimulating the growth and activity of one or a limited number of bacterial species already resident in the colon (Collins and Gibson, 1999). Also, probiotics are viable non-pathogenic microorganisms believed that actively enhance health of the host by improving the microbial balance of the indigenous microflora (Collins and Gibson, 1999). Combination of both probiotic and prebiotic as synbiotic, improves animal health activating the metabolism of one or a limited number of health-promoting bacteria or by selectively stimulating their growth, which improved the welfare of the host (Awad et al., 2009). Moreover, immunological cost savings are realized, with more energy accessible for performance. In addition, synbiotics are able to inhibit excess of oxidative free radicals responsible for cell damage and thereby improve the growth performance of broilers ( $\mathrm{Li}$ et al., 2012). Microorganisms use their nonenzymatic antioxidants, present in the cytosolic and membrane compartments of the cell, in order to protect against oxidative stress (Vossen et al., 2011).

The first line of antioxidant enzymatic defenses include superoxide dismutase (SOD), glutathione peroxidase (GPx), peroxidase (POD), catalase (CAT) and glutathione reductase (GSR) activity. The most important antioxidant enzymes which have antioxidative stress function and can

Table 1.

Chemical compositions of dietary mixtures

\begin{tabular}{lccc}
\hline \multirow{2}{*}{ Nutrient (g/100g) } & \multicolumn{3}{c}{ Diet mixtures } \\
\cline { 2 - 4 } & Starter (1-14) & Finisher & $\mathbf{( 1 5 - 4 2 )}$ \\
\hline Dry matter & & CON & SYN \\
Moisture & 86.5 & 86.8 & 86.4 \\
Crude fat & 13.5 & 13.2 & 13.6 \\
Crude fiber & 3.90 & 4.70 & 4.70 \\
Ash & 4.00 & 5.00 & 5.00 \\
Crude protein & 7.00 & 8.00 & 8.00 \\
Methionine+Cysteine & 22.0 & 20.5 & 20.5 \\
Calcium & 0.671 & 0.714 & 0.710 \\
Phosphorus & 0.95 & 1.10 & 1.10 \\
Lysine & 0.334 & 0.383 & 0.383 \\
Threonine & 1.15 & 1.16 & 1.15 \\
Arginine & 0.804 & 0.807 & 0.805 \\
ME (MJ/kg) & 1.45 & 1.46 & 1.45 \\
& 12.5 & 12.8 & 12.8 \\
\hline
\end{tabular}

eliminate free radicals are GPx and SOD. They also have an inter-protective effect, thus maintaining a healthy balance between oxidants and antioxidants (Aguilar et al., 2007). Malondialdehyde (MDA) is the direct product of lipid peroxidation developed after radical attack on unsaturated fatty acids. MDA content has an important role as an indicator of the lipid peroxidation level and as an indirect reflection of the extent of cell damage (Puvača et al., 2015). MDA may cause deoxyribonucleic acid (DNA) fragmentation, cell membrane structure destruction, cross-linking and accelerate apoptosis. From this reason, the determination of GPx and SOD activity and MDA content can reflect the oxygen free radical level (Wang et al., 2011).

The aim of the study was to determine the effect of a synbiotic (Enterococcus faecium + fructooligosaccharides) on growth and activity of main antioxidant enzymes and MDA concentration in broilers.

\section{MATERIAL AND METHODS}

\section{Chickens and housing}

The experiment was approved by the local Ethics Committee and performed within principles of animal protection. Experiments under in vivo conditions were performed on 500 Cobb 500 hybrid broilers, of both sexes. One-day-old broilers were randomly divided into two different treatments with five replicates of 50 chickens per pen.

\footnotetext{
*Supplements are added on top on basic diet
} 
The light was conducted in accordance to hybrid technology recommendation. Before delivery and receiving of broilers, house temperature zones were preheated to the temperature between $31-33^{\circ} \mathrm{C}$ and was kept constant during the first week of the trial. Every week temperature was decreased for about $2{ }^{\circ} \mathrm{C}$, reaching $20-22{ }^{\circ} \mathrm{C}$ at the end of the $6^{\text {th }}$ week of the experiment. Feed and drinking water were provided ad libitum. For the first 14 days, broilers were fed a starter mixture based on hybrid requirement. During the next 28 days, chickens from the experimental treatment were fed experimental diet (finisher + supplemention). The experimental diet was supplemented with synbiotic (Enterococcus faecim + fructooligosaccharides) (treatment SYN) at dose $1 \mathrm{~g} / \mathrm{kg}$ feed. The control treatment consumed a basal (finisher) diet without any supplemention. The chemical composition of starter and finisher mixtures are shown in Table 1.

\section{Body weight gain, feed intake, feed conversion ratio and mortality}

During the 42-day experimental period, the growth performances of broilers were evaluated by recording body weight (BW), feed intake $(\mathrm{FI})$, feed conversion ratio (FCR) and mortality (M). Broilers were weighted individually at 1,14 and 42 day of age. Feed consumption per pen was recorded at 14 and 42 day of age. The FI was adjusted for weight of chickens at the first day and was calculated after the experimental period of the 14 day and 42 day. The FCR was calculated as feed consumed per unit of body weight gain. Mortality was recorded on a daily bases.

\section{Preparation of blood hemolysate}

Sampling was done on ten broilers per treatment at the end of the $6^{\text {th }}$ week. Blood was collected by heart puncture of broilers into heparinized test tubes. Serum samples from blood were separated by centrifugation (10 min at $2000 \mathrm{rpm}$ and $4{ }^{\circ} \mathrm{C}$ ), afterwards plasma was removed, and the erythrocytes were rinsed 3 times in saline. The resulting erythrocyte pellet was sus- pended in an equal volume of double distilled water and vortexed. After incubation for 1 hour at room temperature, the hemolysate was centrifuged for $15 \mathrm{~min}$ at 2000 rpm and supernatant was collected for further analysis. Performed analyses were previously described by Kostadinović (1998).

\section{Enzyme assay}

Level of hemoglobin, necessary for the expression of the enzymatic activities in hemolysed blood, was determined using a commercial test ('Dialab', Vienna, Austria) on a spectrophotometer (Multiscan MCC 340, Finland). The SOD (EC 1.15.1.1) activity was determined by the spectrophotometric method based on the inhibition of adrenaline reduction to adrenochrome at $\mathrm{pH} 10.2$ (Kostadinović et al., 2011). The GPx (EC 1.11.1.9) activity was determined by spectrophotometric measurement of absorbance at $412 \mathrm{~nm}$ with cumenhydroperoxide as the substrate (Chiu and Stults, 1976). Activity of the GSR (EC 1.6.4.2.) was determined from the rate of NADPH oxidation, by monitoring the absorbance at $340 \mathrm{~nm}$ (Lukaszewicz-Hussain and Moniuszko-Jakoniuk, 2004). The CAT (EC 1.11.1.6.) activity was measured by observing decomposition of hydrogen peroxide. One international unit (IU) was equivalent to one mmol $\mathrm{H}_{2} \mathrm{O}_{2}$ consumed $/ \mathrm{min} / \mathrm{mg}$ protein (Ahn et al., 1998). The determination of POD (EC 1.11.1.7) activity was based on the catalytic oxidation of guaiacole with hydrogen peroxide as an electron acceptor (Kostadinović et al., 2011). Malondialdehyde concentration (MDA) in serum was measured by the 2-thiobarbituric acid assay (Draper et al., 1993). The glutathione (GSH) content in the blood hemolysate was determined using the method reported by Kostadinović et al. (2011).

\section{Data analysis}

The one-way ANOVA analysis and t-test were performed to assess data differences between various treatments using Statistica software version 12 (Statistica, 2013). The data means were considered different at $\mathrm{P}<0.05$. 


\section{RESULTS AND DISCUSSION}

Table 2.

Effect of supplemented synbiotic on growth performances of broilers

\begin{tabular}{lcccc}
\hline Exp. time & Parameter & Control (CON) & Synbiotic (SYN) & SEM \\
\hline \multirow{4}{*}{$0-14$ days } & Body weight BW $(\mathrm{g})$ & $821^{\mathrm{a}}$ & $849^{\mathrm{a}}$ & 16.0 \\
& Feed intake FI $(\mathrm{g})$ & $1100^{\mathrm{a}}$ & $1112^{\mathrm{a}}$ & 98.0 \\
& FCR $(\mathrm{kg} / \mathrm{kg})$ & $1.34^{\mathrm{a}}$ & $1.31^{\mathrm{a}}$ & 0.02 \\
& Mortality $(\%)$ & $0.49^{\mathrm{a}}$ & $0.45^{\mathrm{a}}$ & 0.03 \\
\hline \multirow{4}{*}{$15-42$ days } & Body weight BW (g) & $1286^{\mathrm{b}}$ & $1351^{\mathrm{a}}$ & 21 \\
& Feed intake FI (g) & $2842^{\mathrm{b}}$ & $2876^{\mathrm{a}}$ & 105 \\
& FCR $(\mathrm{kg} / \mathrm{kg})$ & $2.21^{\mathrm{a}}$ & $2.12^{\mathrm{b}}$ & 0.07 \\
& Mortality $(\%)$ & $1.26^{\mathrm{a}}$ & $0.53^{\mathrm{b}}$ & 0.16 \\
\hline \multirow{3}{*}{$0-42$ days } & Body weight BW(g) & $2107^{\mathrm{b}}$ & $2200^{\mathrm{a}}$ & 14.0 \\
& Feed intake FI (g) & $3942^{\mathrm{b}}$ & $3988^{\mathrm{a}}$ & 36.0 \\
& FCR $(\mathrm{kg} / \mathrm{kg})$ & $1.87^{\mathrm{a}}$ & $1.81^{\mathrm{b}}$ & 0.02 \\
& Mortality $(\%)$ & $1.75^{\mathrm{a}}$ & $0.75^{\mathrm{b}}$ & 0.11
\end{tabular}

SEM - standard error $(n=5) ;{ }^{\text {a-b }}$ Treatments indexed with different letter in the same raw are statistically significantly different $(\mathrm{P}<0.05)$

The results given in Table 2 regarding the performance indices of control and supplemented broilers showed that dietary supplementation improved body weight compared to the control treatment during the finisher period, as well during the whole period of trial. This may be explained as the bacteria probiotic beneficial effects of promoting a healthy gastrointestinal tract environment. E. faecim probably improved nutrient absorption from the intestinal mucosa and may be responsible for the improvement in performance of broilers supplemented with synbiotic. This finding is similar to the result reported by Aluwong et al. (2013), who claimed the supplementation with yeast probiotic improved growth rate of male broiler chickens.

Broilers in the synbiotic treatment exhibited a significantly higher $(P<0.05)$ feed intake $(2876 \mathrm{~g})$ compared to control treatment $(2842 \mathrm{~g})$ from day 15 to day 42 . During the whole experimental period, significantly lower feed intake was observed in the control treatment (3942 g) compared to SYN treatment $(3988 \mathrm{~g})$. This may be attributed to improved digestion and absorption of nutrient in the digestive tract due to the presence of live bacteria cells of E. faecim.

Feed conversion ratios were statistically lower $(\mathrm{P}<0.05)$ in the experimental treatment compared to the control treatment during the last 28 days. Furthermore, it is interesting to notice that similar tendency was also recorded throughout the whole experimental period where FCR value reached 1.87 and 1.81 , respectively in treatments CON and SYN. The obtained results indicated that broilers fed with synbiotic were more efficient in converting feed to body mass compared to control broilers.

A probiotic acts by reducing the feed conversion ratio, resulting in an increase in daily live weight gain, which is achieved through a natural physiological way and improvement of digestion by balancing the resident gut micro flora. The differences in final body weight in the sixth week period may also be associated with differences in feed intake. The results of this study are in close collaboration with the Mahdavi et al. (2013) who stated that broilers fed with diet supplemented with probiotic have lower FCR values.

Regarding the broiler mortalities, significant difference $(\mathrm{P}<0.05)$ was noticed during the finisher period, where mortality rates in CON and SYN treatments reached $1.26 \%$ and $0.53 \%$. Moreover, during the period from 0 to 42 days mortalities were also significantly higher $(P<0.05)$ in the control treatment compared to the supplemented treatment. Thus, it can be noticed that synbiotic as a feed additive exhibited beneficial effect on the livability of broilers in comparison with the control broilers. Results of antioxidant enzyme activities and MDA and GSH contents are presented in Table 3. 
Table 3.

Effect of synbiotic on antioxidant enzyme activities and glutathione (GSH) and malondialdehyde (MDA) content of broiler chickens

\begin{tabular}{lccc}
\hline Parameter & Control (CON) & Synbiotic (SYN) & SEM \\
\hline GPx (Umol/L) & $5.10^{\mathrm{b}}$ & $7.36^{\mathrm{a}}$ & 0.02 \\
POD (Umol/L) & $0.35^{\mathrm{b}}$ & $1.09^{\mathrm{a}}$ & 0.06 \\
CAT (U/ml) & $22.0^{\mathrm{b}}$ & $31.5^{\mathrm{a}}$ & 4.70 \\
GSR (U/ml) & $32.8^{\mathrm{b}}$ & $36.0^{\mathrm{a}}$ & 1.70 \\
GSH (U/ml) & $29.0^{\mathrm{a}}$ & $22.5^{\mathrm{b}}$ & 4.20 \\
SOD (Umol/L) & $60.1^{\mathrm{a}}$ & $58.0^{\mathrm{a}}$ & 5.30 \\
MDA (Umol/L) & $8.81^{\mathrm{a}}$ & $6.63^{\mathrm{b}}$ & 0.30 \\
\hline
\end{tabular}

SEM - standard error $(n=5) ;{ }^{a-b}$ Treatments with different letter indexes in the same raw are statistically significantly different $(\mathrm{P}<0.05)$

The data showed a sta-tistically significant $(P<0.05)$ decrease of MDA concentration (6.63 Umol/L) in the synbiotic treatment compared to the control treatment (8.81 Umol/L). Moreover, significantlly higher activity levels of all examined enzymes, except of SOD, were noted in the broiler treatment supplemented with synbiotic.

Results manifested significant increase $(\mathrm{P}<0.05)$ in $\mathrm{POD}$ and GPx activity, while significant decrease $(P<0.05)$ in MDA and GSH contents were noted in treatment CON compared to the experimental treatment. Therefore, it has been shown that nutrition plays a vital role in maintaining the pro-oxidant/antioxidant balance (Aluwong et al., 2013). In the present study, the increase in catalase, glutathione peroxidase and glutathione reductase activities were also noticed. The increased activity of these antioxidant enzymes may be attributed to the age, colonization resistance, and susceptibility to environmental pathogens of the broilers.

Obtained results were in agreement with the previous observations of Capcarova et al. (2010) and Rajput et al. (2013) who reported that some microorganisms could help in the oxidation resistance, hydroxyl radical trapping and in antioxidant capacity increase. The results indicated synbiotic could improve the antioxidant activities and reduce the damage caused by free radicals.

\section{CONCLUSIONS}

The present study revealed that supplementation of broiler diets with the synbiotic relatively increased the body weight of broilers, while feed intake was improved slightly in the supplemented treatment compared to the control treatment. Thus, the feed conversion ratio of broilers was significantly different in the experimental treatment in comparison to the control broilers. According to the GPx, POD, CAT and GSR results, significantlly higer activities were noted, while there was observed a decrease in MDA content in the suplementary treatment. Therefore, the findings of the present study indicated that diets containing synbiotic can be used for improving broiler performance and blood antioxidative status of broiler chickens.

\section{ACKNOWLEDGEMENTS}

The paper is a part of the research work on the project III46012 financed by the Ministry of Education, Science and Technological Development of the Republic of Serbia.

\section{REFERENCES}

1. Aguilar, A., Alvarez-vijande, R., Capdevila, S., Alcoberro, J., Alcaraz, A. (2007). Antioxidant patterns (superoxide dismutase, glutathione reductase and glutathione peroxidase) in kidneys from non-heart beating-donors: experimental study. Transplantation Proceedings Journal, 39 (1), 249-252.

2. Ahn, D.U., Sell, J. L., Chen, X., Wu, C., Lee, J. L. (1998). Effects of dietary vitamin $E$ supplementation on lipid oxidation and volatiles content of irradiated, cooked turkey meat patties with different packaging. Poultry Science, 77 (6), 912-920.

3. Aluwong, T., Kawu, M., Raji, M., Dzenda, T., Govwang, F., Sinkalu, V., Ayo, J. (2013). Effect of yeast probiotic on growth, antioxidant enzyme activities and malondialdehyde concentration of broiler chickens. Antioxidants, 2 (4), 326-339.

4. Awad, W. A., Ghareeb, K., Abdel-Raheem, S., Böhm, J. (2009). Effects of dietary inclusion of probiotic and synbiotic on growth performance, organ weights, and intestinal histomorphology of broiler chickens. Poultry Science, 88 (1), 49-56. 
5. Capcarova, M., Weiss, J., Hmar, C., Kolesarova, A., Pal, G. (2010). Effect of Lactobacillus fermentum and Enterococcus faecium strains on internal milieu, antioxidant status and body weight of broiler chickens. Journal of Animal Physiology and Animal Nutrition, 94 (5), 215224.

6. Castanon, J. I. R., (2007). History of the use of antibiotic as growth promoters in European poultry feeds- a review. Poultry Science, 86 (11), 2466-2471.

7. Chiu, D. T. Y., Stults, F. H. (1976). Purification and properties of rat lung soluble glutathione peroxidase. Biochimica et Biophysica Acta, 445 (3), 558-566.

8. Collins, M. D., Gibson, G. R. (1999). Probiotics, prebiotics, and synbiotics: approaches for modulating the microbial ecology of the gut. The American Journal of Clinical Nutrition, 69 (5), 1052s-1057s.

9. Draper, H. H., Squires, E. J.,Mahmoodi, H., Wu, J., Agarwal,S., Hadley, M. (1993). A comparative evaluation of thiobarbituric acid methods for the determination of malondialdehyde in biological materials. Free Radical Biology \& Medicine, 15, 353-363.

10. Kostadinović, Lj. (1998). Effect of coccidiosis on broilers parameters and determination residues of coccidiostatics in broiler's tissue, PhD Thesis, Faculty of Sciences, University of Novi Sad, Serbia.

11. Kostadinović, Lj., Pavkov, S., Lević, J., GalonjaCoghill, T., Dozet, G., Bojat, N. (2011). Effect of sulphachloropyrazine on antioxidative systems in blood and liver of broilers. Acta Veterinaria Brno, 80 (2), 165-170.

12. Li, W. F., Huang, Q., Li, Y.L., Rajput, I. R., Huang, Y., Hu, C.H. (2012). Induction of synbiotic strain Enterococcus faecium EF1 on the production of cytokines, superoxide anion and prostaglandin E2 in a macrophage cell line. Pakistan Veterinary Journal, 32 (4), 530-534.

13. Lukaszewicz-Hussain, A., Moniuszko-Jakoniuk, J. (2004). Liver catalase, glutathione peroxidase and reductase activity, reduced glutathione and hydrogen peroxide levels in acute intoxication with chlorfenvinphos, an organophosphate insecticide. Polish Journal of Environmental Studies, 13 (3), 303-309.
14. Mahdavi, S., Zakeri, A., Mehmannavaz, Y., Nobakht, A. (2013). Comparative study of probiotic, acidifier, antibiotic growth promoters and prebiotic on activity of humorallmmune and performance parameters of broiler chickens. Iranian Journal of Applied Animal Science, 3 (2), 295299.

15. Marrero, Y., M.E. Burrola-Barraza, Y. Castillo, L.C. Basso, C.A. Rosa, O. Ruiz, E. GonzalezRodriguez, (2013). Identification of Levica yeasts as a potential ruminal microbial additive. Czech Journal of Animal Science, 58 (10), 460-469.

16. Puvača, N., Stanaćev, V., Glamočić, D., Lević, J., Perić, L., Stanaćev, V., Milić, D. (2013). Beneficial effects of phytoadditives in broiler nutrition. Worlds Poultry Science Journal, 69 (1), 27-34.

17. Puvača, N., Kostadinović, Lj., Popović, S., Lević, J., Ljubojević, D., Tufarelli, V., Jovanović, R., Tasić, T., Ikonić, P., Lukač, D. (2015). Proximate composition, cholesterol concentration and lipid oxidation of meat from chickens fed dietary spice addition (Allium sativum, Piper nigrum, Capsicum annuum). Animal Production Science 88, (http://dx.doi.org/10.1071/AN15115).

18. Rajput, I. R., Li, Y. L., Xu, X., Huang, Y., Zhi, W. C., Yu, D. Y. Li, W. (2013). Supplementary effects of Saccharomyces boulardii and Bacillus subtilis B10 on digestive enzyme activities, antioxidation capacity and blood homeostasis in broiler. International Journal of Agriculture and Biology, 15 (3), 231-237.

19. Statistica (Data Analysis Software System) (2013). v.12.0., Stat-Soft, Inc., USA (www.statsoft.com).

20. Vossen, E., Ntawubizi, M., Raes, K., Smet, K., Huyghebaert, G., Arnouts, S., De Smet, S. (2011). Effect of dietary antioxidant supplementation on the oxidative status of plasma in broilers. Journal of Animal Physiology and Animal Nutrition, 95 (2), 198-205.

21. Wang, H. F., Zhong, X. H., Shi, W. Y., Guo, B. (2011). Study of malondialdehyde (MDA) content, superoxide dismutase (SOD) and glutathione peroxidase (GSH-Px) activities in chickens infected with avian infections bronchitis virus. African Journal of Biotechnology, 10 (45), 9213-9217. 


\section{УТИЦАЈ СИНБИОТИКА НА РАСТ И АНТИОКСИДАТИВНИ СТАТУС КРВИ КОД БРОЈЛЕРСКИХ ПИЛИЋА}

Сања Ј. Поповић ${ }^{1 *}$, Љиљана М. Костадиновић ${ }^{1}$, Никола М. Пувача ${ }^{2}$, Јованка Д. Левић ${ }^{1}$, Оливера М. Ђурагић ${ }^{1}$, Бојана М. Кокић ${ }^{1}$, Ивана С. Чабаркапа ${ }^{1}$, Марина В. Врањеш ${ }^{3}$

${ }^{1}$ Универзитет у Новом Саду, Научни институт за прехрамбене технологије, Булевар цара Лазара 1, 21000 Нови Сад, Србија

${ }^{2}$ Универзитет у Новом Саду, Пољопривредни фракултет, Трг Доситеја Обрадовића 8, 21000 Нови Сад, Србија

${ }^{3}$ Институт за примену науке у пољопривреди, Булевар деспота Стефана 68б, 11000 Београд, Србија

Сажетак: Циљ истраживања био је да се испита ефекат синбиотика на производне перформансе и антиоксидативни статус крви бројлерских пилића. Експеримент је изведен на 500 једнодневних пилића оба пола, подељених у у два третмана са по 250 пилића. Сваки третман је подељен у пет група који су представљали пет понављања огледа. Пилићи на контролном третману (CON) су храњени смешама без додатка синбиотика, док је у експерименталној смеши додат синбиотик у концентрацији $1 \mathrm{~g} / \mathrm{kg}$ хране (SYN) у финишер фази која је трајала од 15 до 42 дана огледа. Додатак синбиотика у исхрани бројлерских пилића довео је до пораста телесне масе пилића на крају 14 и 42 дана огледа. Током првих 14 дана, конверзија хране је била значајно побољшана $(P<0,05)$ у SYN третману $(1,49)$ у поређењу са контролним третманом (1,53). Активност глутатион пероксидазе, пероксидазе, глутатион редуктазе и каталазе била је значајно виша $(P<0,05)$ у третману где је коришћен синбиотик у исхрани пилића у поређењу са CON третманом, при чему је активности супероксид дисмутазе била изузетак. Такође, статистички значајан пад $(P<0,05)$ у садржају малондиалдехида и глутатиона забележен је у експерименталном третману. Узимајући у обзир добијене резултате, може се закључити да синбиотик може бити примењен као промотер раста и као природни антиоксидант у исхрани у бројлерских пилића

Кључне речи: бројлер, синбиотик, промотор раста, антиоксидативни статус

Received: 24 September 2015

Accepted: 5 November 2015 